\title{
Polymerization Degree of Phytochelatin in Contaminated Soil Phytoremediation of Manganese in Hibiscus Sabdariffa Linn Var Sabdariffa
}

\author{
Mavoungou Ange Younes, PhD \\ University of Lorraine, France. Superior School professorship and Education \\ Lepengue Alexis Nicaise, $M c f$ \\ M'Batchi Bertrand, Pr \\ Masuku Science and Technology University (USTM). \\ Laboratory Plant Physiology and Plant Protection, \\ Research Unit agrobiology, Gabon
}

doi: 10.19044/esj.2016.v12n33p482 URL:http://dx.doi.org/10.19044/esj.2016.v12n33p482

\begin{abstract}
The aim of this study is to determine the usefulness of roselle (Hibiscus sabdariffa L. var sabdariffa), and its polymerization degree of phytochelatins (PCs) for contaminated soil Mn phytoremediation. Sorrel plants grow in three highly contaminated soils $\mathrm{Mn}(4 \mu \mathrm{M}, 6 \mu \mathrm{M}$ and $8 \mu \mathrm{M})$ in control conditions. Roselle accumulates large amounts of Mn in the leaves in the various contaminated environments Mn. The removal rate of absorption in the higher Mn was observed in the medium $8 \mu \mathrm{M} \mathrm{Mn}$. In parallel, the middle $4 \mu \mathrm{M}$ Mn showed the lowest $\mathrm{Mn}$ extraction rate. Induced oxidative stress due to the Mn content, generates the highest level in ascorbate $8 \mu \mathrm{M} \mathrm{Mn}$. The medium $8 \mu \mathrm{M} \mathrm{Mn}$ shows an induction of 9 to 16 times the amount of $\gamma$-glutamylcysteine and against a low induction of $\gamma$ glutamylcysteine in the medium $4 \mu \mathrm{M} \mathrm{Mn}$. Accordingly, the total content phytochelatin (PC) was 7-9 times higher $8 \mu \mathrm{M}$ Mn. In addition, PCs high polymerization degree were observed in $8 \mu \mathrm{M}$ Mn (PC4, PC6 and PC7), while PC2 and PC3 occurred in $4 \mu \mathrm{M} \mathrm{Mn}$ and $6 \mu \mathrm{M}$ Mn only. The correlation analysis shows that $8 \mu \mathrm{M}$ Mn phytoremediation capacity is associated with the PCs synthesis and their polymerization degree is high.
\end{abstract}

Keywords: $H$ sabdariffa, Phytochelatin, Phytoremediation, Manganese, Polymerization degree.

\section{Introduction}

Manganese is one of toxic metals in Moanda (Gabon) due to mining. Phytoremediation, which is an ecological sanitation technology that uses 
plants to extract the toxic metals that contaminate the environment (soil, water, air). This technique includes several groups such as phytodegradation, rhyzofiltration, phytostabilisation, phytovolatilisation and phytoextraction (Jamal, 2002). Phytoextraction is the most used. By this technique, Plants bioconcentrate the soil toxic metals in their leaves. The bioconcentration manganese in a plant depends on soil physical and chemical properties and those ions manganic. $\mathrm{Mn}^{2}+$ ions become toxic to plants because of reactive oxygen species production (ROS). ROS, to lethal doses, adverse effects from lipids, proteins and nucleic acids. Non-toxic concentrations, ROS are growth regulators and controlled development. Oxidative stress induced by ROS to high concentrations triggers plant defense systems. Non-enzymatic antioxidants such as glutathion (GSH) and ascorbate (ASA) monitor plant hydrogen peroxide $\left(\mathrm{H}_{2} \mathrm{O}_{2}\right)$ content. The latter degradation allows the glutathion redox status monitor cell plant and contributes to the detoxification and balance of metals (Török, 2015). Detoxification of metals in plants is accomplished because of the metal distribution in the tissues as trichomes apoplastic and cell walls. Then by chelating of the metal by a ligand, followed by vacuolar sequestration metalligand complex (Li and al., 1997).

Phytochelatins (PCs) are small structure of metal-peptide bonds ( $\mathrm{\gamma}$ Glu-Cys) n-Gly, where the value of (n) ranges from 2 to 11 , and whose synthesis is induced by several metals, such as Mn (Mavoungou, 2015). They are composed of three amino acids, glutamine (Glu), cysteine (Cys), and glycine (Gly) with Glu and Cys residues linked by a $\gamma$-carboxyl amide bond. PCs are structurally related to the tripeptide glutathione (GSH; $\gamma$ GluCysGly) and are not synthesized at the ribosome level (Pal, 2012). Phytochelatin synthesis is catalyzed by the phytochelatin synthase (EC 2.3.2.15] from the substrate and GSH tripeptide thiol linked to the presence of metal ions, such as Cd, Cu, Zn, Ag, Hg, Pb, Mn (Grill, 1989; Mavoungou, 2015) GSH is responsible for the biosynthesis phytochelatins substrate.

Manganese ore is essential to plants and is involved in many physiological processes. In Gabon, the elimination of this mineral in the environment at high levels, is a major challenge for the bioremediation of natural environments. The absorption, translocation and tolerance of manganese are analyzed within the Hibiscus sabdariffa L var sabdariffa. The accumulation of manganese induces increasing concentrations of $\mathrm{H}_{2} \mathrm{O}_{2}, \mathrm{O}_{2}$ and lipid peroxidation in the leaves of $H$ sabdariffa. In the latter case, it has been accompanied by a rise in peroxidase (POX), ascorbate peroxidase (APX) and glutathion peroxidase activity (GPX). Exposure of $H$. sabdariffa Mn leads to an apoplastic acidosis due to the Mn of binding to the cell wall. For this, the Mn influx into the cytosol has been reduced. 
This study shows that the Mn active protection systems and $H$ sabdariffa $L$ var sabdariffa manganese stores in its high contents in vacuolar system. The aim of this work was firstly to evaluate the usefulness of roselle in the phytoremediation of contaminated soil Mn and secondly to compare the impact of three levels of $\mathrm{Mn}$ in Roselle to better understand the system of phytoremediation, the changes induced in non-enzymatic antioxidants such as ascorbate and glutathion, but also to examine the level and synthesis phytochélatin.

\section{Materials and methods}

Materials and plants treatment

$H$. sabdariffa $\mathrm{L}$. var sabdariffa grows in controlled experimental conditions and at a temperature of $30^{\circ} \mathrm{C}$ day $/ 23^{\circ} \mathrm{C}$ night and a relative humidity of $75 \%$ for 1 month and two weeks in the nutrient solution Hoagland $0.08 \mathrm{M} / \mathrm{L}$. $6 \mathrm{~g} \mathrm{H}$ sabdariffa plant growing in a pot volume $\mathrm{V}=400$ $\mathrm{ml}$ each of which contains a precise amount of $\mathrm{Mn}(4 \mu \mathrm{M}, 6 \mu \mathrm{M}$ and $8 \mu \mathrm{M})$ to $22 \circ \mathrm{C}$.

\section{Determination and Mn elimination}

The samples were oven-dried at $70^{\circ} \mathrm{C}$ for 24 hours to assess the Mn content in the tissues. These are ground and digested with nitric acid and hydrogen peroxide using the digestion system in microwave Berghof (model 2 MWS, German). The concentration of Mn was determined by the atomic absorption spectrophotometer (GBC dual direction AA, Australia).

\section{Protein analysis}

The rate of total protein was estimated using Bradford method (1976) using bovine serum albumin.

\section{Ascorbic acid (ASA) determination}

Using method described by Török and al., (2005) roselle samples were ground to a fine powder using liquid nitrogen. ASA was extracted from $200 \mathrm{mg}$ of a sample metaphosphoric acid $1.5 \mathrm{~mL}(1.5 \%)$. The solutions were centrifuged for $10 \mathrm{~min}$ at $10,000 \mathrm{~g}$ at $4^{\circ} \mathrm{C}$, then the supernatants were filtered. Total ASA (ASA reduced and dehydroascorbate, "DHA") was determined by adding $0.26 \mathrm{mM}$ dithiothreitol to the supernatant. The samples were stored at room temperature for 15 minutes to complete reduction. For the measurement of reduced ascorbic acid, the water was added $20 \mu \mathrm{L}$ instead of dithiothreitol. The samples were analyzed by HPLC as described by the method of Szalia et al., (2004). 


\section{Thiols assessment}

Two hundred and fifty milligrams of roselle sample were homogenized in a mortar with $1 \mathrm{~mL}$ of $0.1 \mathrm{M} \mathrm{HCl}$ solution, then it is centrifuged for $10 \mathrm{~min}$ at $20000 \mathrm{~g}$ at $4^{\circ} \mathrm{C}$. The method described by Kranner and al., (1996) was used to measure the total thiol content. The determination of oxidized thiols need blockage of thiols reduced by $\mathrm{N}$ ethylmaleimide. The surplus of the latter is removed by extraction with toluene, and reducing oxidized thiols is completed the next step. The fluorescent labeling of the thiol was carried out by monobromobimane. The separation and quantification of thiols have been carried out respectively by HPLC and a fluorescence detector.

\section{Phytochelatin and phytochelatin synthase assessment}

The method described by Chen and al., (1997) has allowed to measure the concentration of phytochelatins (PCs) and activity of phytochelatins synthases (PCS). Samples roselle (600mg) were ground with $700 \mu \mathrm{L}$ of extraction buffer containing $50 \mathrm{mM}$ Tris- $\mathrm{HCl}, 10 \mathrm{mM}$ mercaptoethanol (ME) and 14\% glycerol. The samples were centrifuged for $10 \mathrm{~min}$ at $10,000 \mathrm{~g}$. For the determination of PC, the supernatant was mixed with the reaction mixture containing 200mM TRIS ( $\mathrm{pH} 8.0), 1 \mathrm{mM}$ betamercaptoethanol, $10 \mathrm{mM}$ GSH and $0.5 \mathrm{mM} \mathrm{Cd}\left(\mathrm{NO}_{3}\right)_{2}$ in a volume total of $100 \mu \mathrm{L}$. Concentrations PCs were determined before and after $60 \mathrm{~min}$ of reaction. The latter is stopped by the addition of $30 \mu \mathrm{L}$ of $50 \%$ sulfosalicylic acid for calculating the activity of PC. The PC content was measured by reverse phase HPLC as described by the method of Szalia et al., (2013).

\section{Statistical analysis}

The average result is calculated from the results of three experiments. The significant differences between the control and the treated samples were calculated using the t test. Correlation analysis was made from the method of Guilford (1950).

\section{Results:}

\section{Heavy metals effect Mn on dry weight roselle leaves}

The sorrel plants were exposed to increasing concentrations of three order $2 \mathrm{Mn}(4 \mu \mathrm{M}, 6 \mu \mathrm{M}$ and $8 \mu \mathrm{M})$ for one month. The leaves of plants exposed to different environments were weighed to assess the influence of manganese on the growth of plants from the dry weight of the leaves. The leaves of the control plants have a dry weight of $0.19 \mathrm{~g}$. Plants exposed to the contents of $\mathrm{Mn}$ respectively $4 \mu \mathrm{M}, 6 \mu \mathrm{M}$ and $8 \mu \mathrm{M} \mathrm{Mn}$ provide a dry weight difference compared to the controls of $0.03(16 \%), 0.04(22 \%)$ and $0.06 \mathrm{~g}$ (32\%) reduction after one month. 


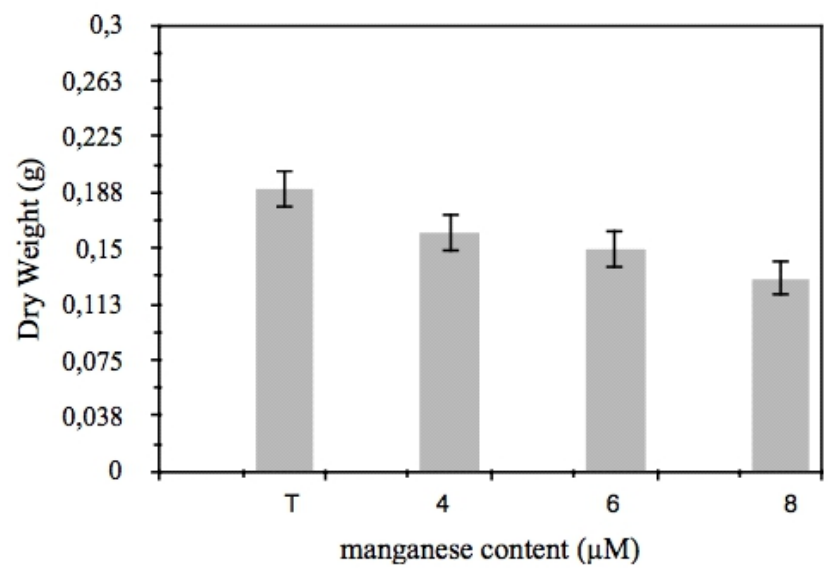

Figure 1: Mn effect on dry weight roselle leaves

\section{Mn effect on total concentration of soluble proteins}

High concentrations of $\mathrm{Mn}$ cause the increase in the content of soluble proteins. Indeed, a low $\mathrm{Mn}(4 \mu \mathrm{M})$ induces little soluble protein $(0.70 \mathrm{mg} / \mathrm{g})$ compared to a high content of $8 \mu \mathrm{M}$ Mn that provided $1.27 \mathrm{mg} / \mathrm{g}$ of soluble proteins. Results suggest that metabolic dysfunction caused by excess Mn assesses the content of soluble proteins.

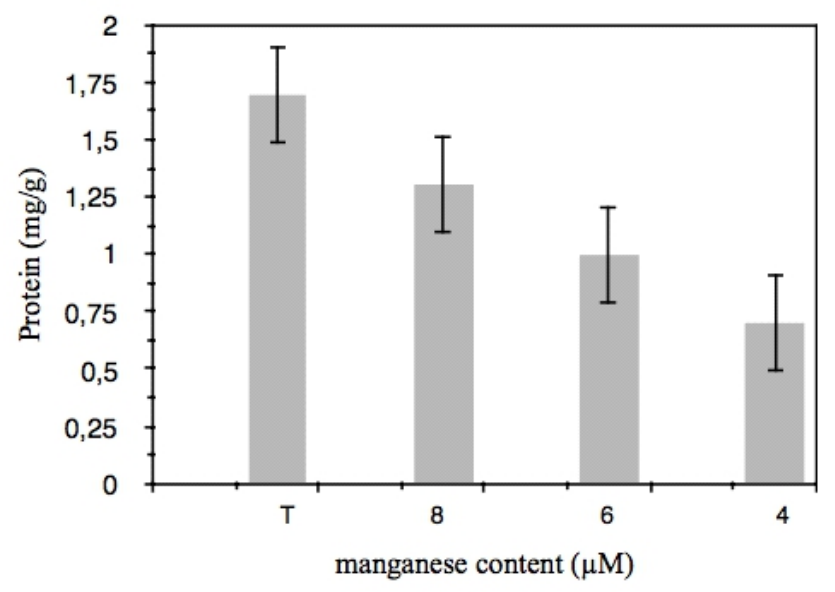

Figure 2: Effect of decreasing concentration Mn on proteins content.

Mn effect on quantity and reduction potential of ascorbate and dehydroascorbate

In the control sample, the total ascorbate (ASA + DHA) is the highest in the absence of Mn content. We see a gradual decrease in the total ascorbate following the concentrations of $\mathrm{Mn}(4 \mu \mathrm{M}, 6 \mu \mathrm{M}$ and $8 \mu \mathrm{M})$. The reduction potential of DHA / ASA ratio is affected when exposed to Mn due to the reduction of DHA and ASA. 


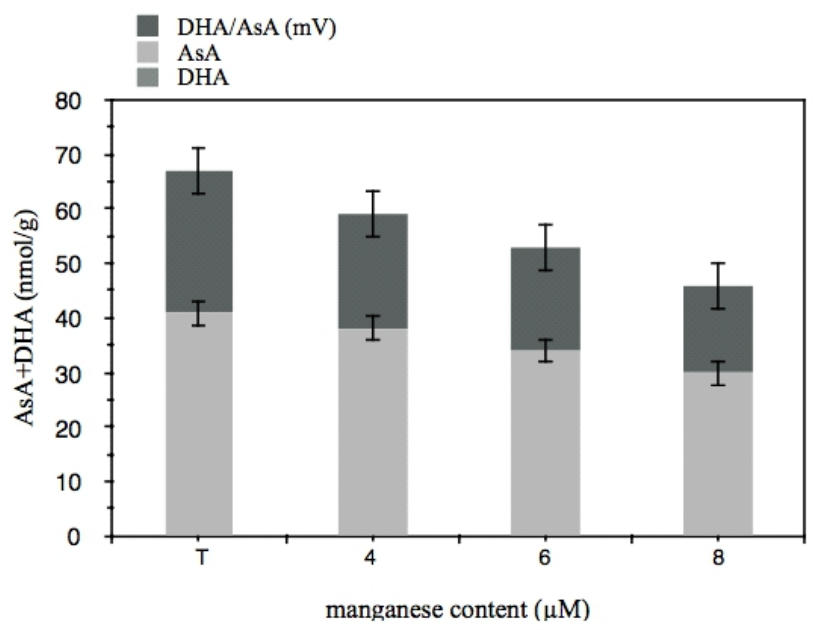

Figure 3: Mn effect on ascorbate (ASA), dehydroascorbate (DHA) concentration and their reduction potential (DHA/ASA). The plants were treated with Mn (T: control) for one month.

\section{Mn effect on glutathion metabolism and thiol / thiol disulfide linked to potential reduction}

The highest concentrations Cys+cysteine were observed in the control $(67.5 \mathrm{nmol} / \mathrm{g})$. While the lowest levels $(11.25 \mathrm{nmol} / \mathrm{g})$ were detected upon exposure to three concentrations of Mn. The potential for reducing the torque cysteine/Cys decreased after treatment with Mn. The concentration of glutamylcysteine (Glu-Cys) gradually increases to $45 \mathrm{nmol} / \mathrm{g}$ after treatment at $\mathrm{Mn}$. However, it has a very low concentration in the control $(7.6 \mathrm{nmol} / \mathrm{g})$. In addition, the concentration of torque y-Glu-Cys/2-Glu-Cys segments of same after treatment $\mathrm{Mn}$ of 2 to $4 \mathrm{nmol} / \mathrm{g}$. The reduction potential of the couple Glu-Cys increased after treatment with Mn. The GSH content is high $(15.75 \mathrm{nmol} / \mathrm{g})$ in the controls without Mn. The GSSG concentration is even higher in the control. Therefore torque GSSG/GSH is as high in the control. However, it gradually decreases after treatment with $\mathrm{Mn}$ of 11.5 to $10 \mathrm{nmol} / \mathrm{g}$. The content of cysteinylglycine (Cys-Gly) is low in the control and gradually increases after treatment with $\mathrm{Mn}$. 

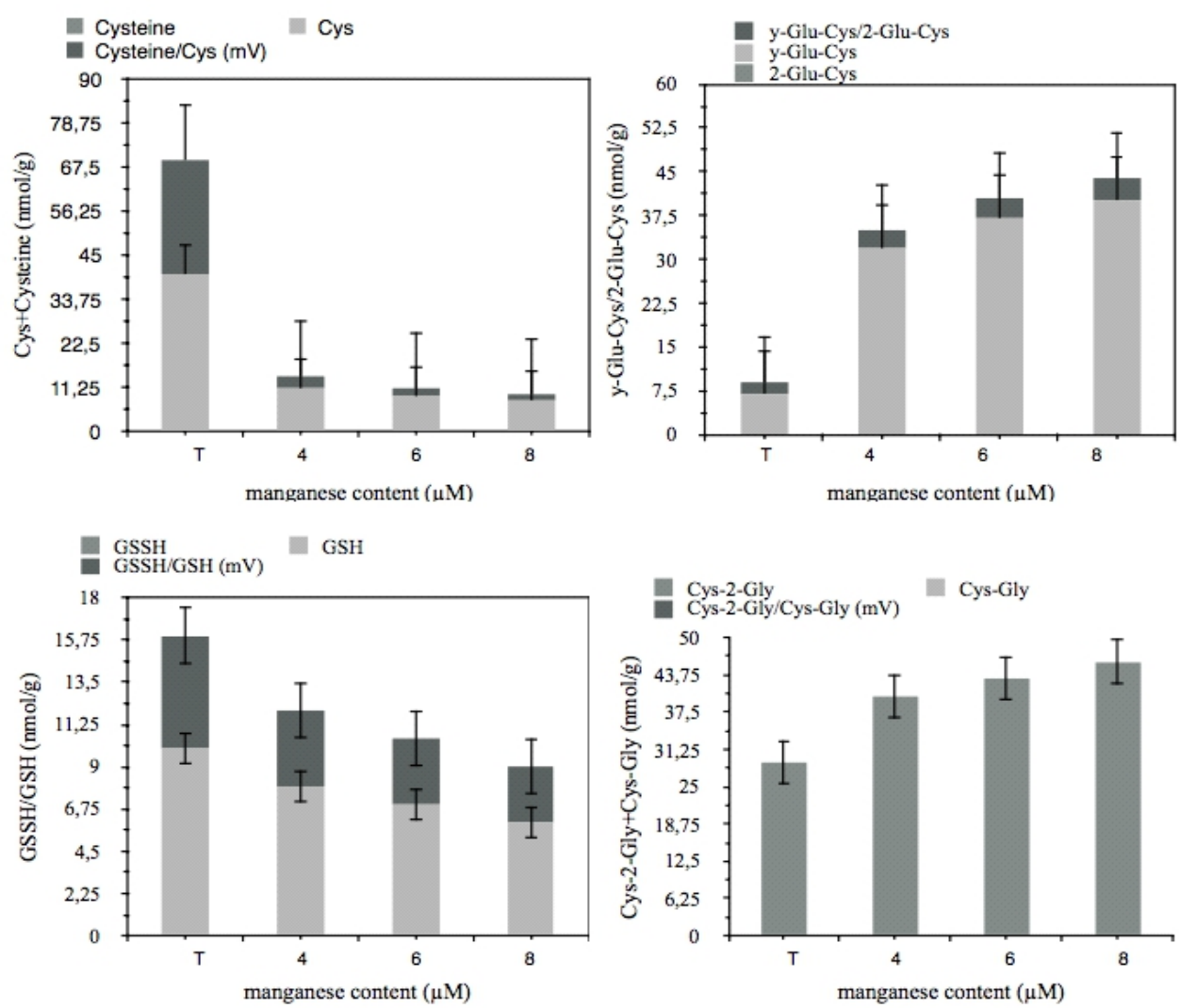

Figure 4: Mn effect on glutathion, thiols concentration and their potential reducing activation. The plants were treated with Mn (T: control) for one month.

\section{Mn effect on phytochelatins synthesis}

The activity of phytochelatins is low in the control pka 29l/g. Contrariwise, it increases progressively after treatment Mn 40 to 45 pka l/g.

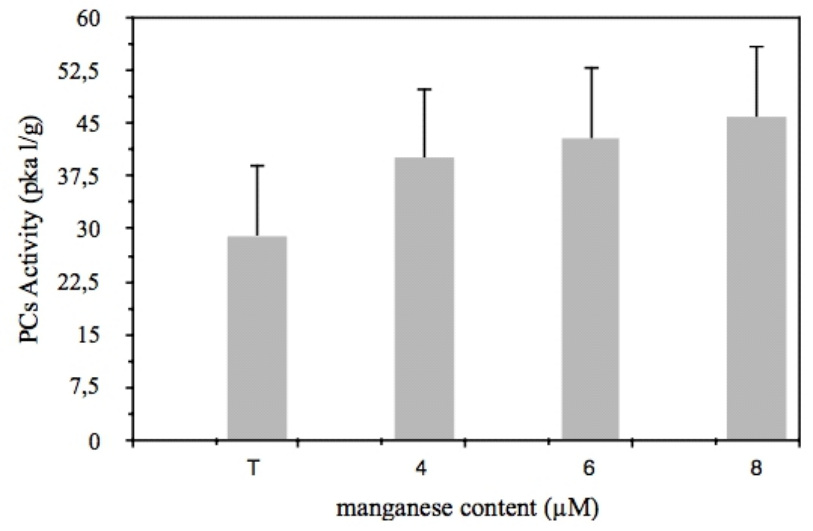

Figure 5: Mn effect on phytochelatins activity. The plants were treated with Mn (T: control) 
Table 1 below shows that the amount of PC2 and PC3 are low in the control sample. Their concentrations increase after treatment with Mn PC4, PC6 and PC7 do not appear in the control. However, they were detected after treatment with Mn. Furthermore, we find that the concentration of PC6 and PC7 are 9-11 times higher than the concentration of PC2, PC3 and PC4.

\begin{tabular}{|c|c|c|c|c|c|}
\hline \multirow{2}{*}{ plant specie } & \multicolumn{5}{|c|}{ PCs (nmol/g fresh weight) } \\
\hline & PCs & T & $4 \mu \mathrm{M} M$ & $6 \mu \mathrm{M} M$ & $8 \mu \mathrm{M} \mathrm{Mn}$ \\
\cline { 2 - 6 } & PC2 & $0,90+/-00.27$ & $1.21 \pm 00.33$ & $1.41 \pm 00.43$ & $2,03 \pm 00.4$ \\
\cline { 2 - 6 } & PC3 & $9.80+/-00.4$ & $11.57 \pm 01$ & $13.98 \pm 01.7$ & $15,63 \pm 01.9$ \\
\cline { 2 - 6 } & PC4 & 0 & $3.59 \pm 00.5$ & $7,99 \pm 00.98$ & $9,23 \pm 1,3$ \\
\hline \multirow{3}{*}{ H. sabdariffa } & PC6 & 0 & $41.97 \pm 0.63$ & $50,90 \pm 0.47$ & $53,21 \pm 0.8$ \\
\cline { 2 - 6 } & PC & 0 & $44.11 \pm 0.5$ & $34,83 \pm 0.79$ & $34,11 \pm 0.9$ \\
\hline & PC7 & 0 & $102,45_{ \pm 2,06}$ & $109,11 \pm 3,53$ & $109.64 \pm 5,3$ \\
\hline
\end{tabular}

Table 1: phytochelatins (PC) contained in sorrel exposed to Mn (T: control) for one month.

\section{Roselle phytoremediation capacity}

The determination of the $\mathrm{Mn}$ concentrations before and after treatment of sorrel plants

(Table 2) revealed the phytoremediation capacity of sorrel. Sorrel has a pretty good ability to absorb $\mathrm{Mn}$ in a soil sample. After treatment with Mn, the sorrel plants have a potential for absorption of $88 \%$ compared to the control sample.

\begin{tabular}{|c|c|c|c|c|}
\hline \multirow{2}{*}{ plant specie } & \multicolumn{4}{|c|}{ The heavy metal concentration (mg/g, fresh weight) after phytoremediation } \\
\hline \multirow{2}{*}{ H.Sabdariffa } & $\mathrm{T}$ & $4 \mu \mathrm{M} \mathrm{Mn}$ & $6 \mu \mathrm{M} \mathrm{Mn}$ & $8 \mu \mathrm{M} \mathrm{Mn}$ \\
\cline { 2 - 5 } & $0.019 \pm 0.037$ & $1.42 \pm 0.028$ & $1.83 \pm 0.043$ & $1.79 \pm 0.033$ \\
\hline
\end{tabular}

Table 2: Mn potential absorption by roselle

\section{Discussion:}

Phytochelatins (PC) are synthesized from GSH and have different degrees of polymerization based on the number of incorporated dipeptides (Glu-Cys). The reaction is catalyzed by phytochelatin synthase (PCS). The results of this study showed the relevance of Hibiscus sabdariffa Linn var sabdariffa for phytoremediation of polluted soils $\mathrm{Mn}(4 \mu, 6 \mu \mathrm{M}$ and $8 \mu \mathrm{M})$. The concentrations of Mn generate PCs rates that have a relationship with the other parameters studied: GSH, GSSG, Cys/cysteine, Glu-Cys/Cys bis, Glu-Cys-Gly/Cys-Gly-bis. Similar results were reported by Mavoungou et al., (2015). The extraction of Mn has not reduced the fresh weight of $H$. 
sabdariffa. Therefore, in this study, this species can eliminate up to $8 \mu \mathrm{M} \mathrm{Mn}$. Similarly for the other author, it was also observed that low concentrations of Mn did not affect the growth of $H$. sabdariffa (Ontod and al., 2009). The slight change in the total content of soluble proteins after treatment with $\mathrm{Mn}$ in $H$. sabdariffa shows that metabolism has not been seriously affected in this case and, therefore, it is appropriate for phytoextraction. Phytoextraction capacity of $H$. sabdariffa has been associated with the high concentration of ASA and ASA ratio/DHA after treatment with Mn. After treatment with Mn a large quantity of Glu-Cys content in this genotype generated GSH synthesis. The formation of GSH is reduced due to the synthesis of Cys-Glu. The low GSH in $H$. sabdariffa explains the immediate use of GSH for the synthesis of PC, because the amount of its degradation product, Cys-Gly, remained low after treatment with Mn. Phytoremediation capacity of $H$. sabdariffa is associated with the synthesis of PC with a high degree of polymerization (PC4, PC6 and PC7). In Fucus spp, it was observed that the synthesis of the longest chain PC (PC7) comes from a highly contaminated site in Cd (Pawlik-Skowronska and al., 2007).

\section{Conclusion}

The combination of ability in phytoremediation and $H$. sabdariffa degree of polymerization PC indicates a Mn accumulation and a simultaneous synthesis of long chains of PC. Furthermore, a high concentration PCn class of PC with n greater than 6 was possible due to a strong induction of the synthesis of Glu-Cys.

\section{References:}

1. Hossain ; M. A and al., 2012. Molecular Mechanism of Heavy Metal Toxicity and Tolerance in Plants: Central Role of Glutathione in Detoxification of Reactive Oxygen Species and Methylglyoxal and in Heavy Metal Chelation. Hindawi Publishing Corporation Journal of Botany Volume 2012, Article ID 872875, 37 pages doi:10.1155/2012/872875

2. Lallemand-Barr. A, 1993. Méthodes de dépollution des sols et des eaux pollués par les métaux. Document public, service sol et sous-sol Direction Technique de l'Ingénieriede I'Environneme (BRGM).

3. Clemens. S, 2006. Evolution and function of phytochelatin synthases. Journal of Plant Physiology 163- 319-332.

4. Park. J and al., 2012. The phytochelatin transporters AtABCC1 and AtABCC2 mediate tolerance to cadmium and mercury. The Plant Journal 69, 278-288.

5. Hooda. V, 2007. Phytoremediation of toxic metals from soil and waste water. Journal of Environmental Biology 28(2) 367-376. 
6. Brzyska. M, Grzywnowicz. k, Lobarzewski. J and al., 1993. Influence of reduced glutathione (GSH) and metal ions on soluble and immobilized cabbage peroxidase. journal of Mo\&d.c Catalysis, 78 (1993) 113-120

7. Cruz. B. H, Diaz-Cruz. J. M and al., 2002. Differential pulse voltammetric study of the complexation of $\mathrm{Cd}(\mathrm{II})$ by the phytochelatin (g-Glu Cys) ${ }_{2}$ Gly assisted by multivariate curve resolution. Journal of Electroanalytical Chemistry 520 111-118

8. Clemens. S, Kim. E. J, and al., 1999. Tolerance to toxic metals by a gene family of phytochelatin synthases from plants and yeast. The EMBO Journal Vol.18 No.12 pp.3325-3333.

9. Scarano. G and Morelli. E, 2002. Characterization of cadmium- and lead- phytochelatin complexes formed in a marine microalga in response to metal exposure. BioMetals 15: 145-151.

10. Mavoungou. A. Y, and al., 2015. ANTIOXYDANTS ET PHYTOCHELATINES DANS LA TOLERANCE ET L'ACCUMULATION DU MANGANESE CHEZ L'HIBISCUS SABDARIFFA LINN. European Scientific Journal July 2015 edition vol.11, No.21 ISSN: 1857 - 7881 (Print) e - ISSN 1857- 7431.

11. Cobbett. C. S, 2000. Phytochelatins and Their Roles in Heavy Metal Detoxification. Plant Physiology, July 2000, Vol. 123, pp. 825-832.

12. Török. A and al., 2015. Phytoremediation capacity of aquatic plants is associated with the degree of phytochelatin polymerization. Journal of Hazardous Materials 299 371-378.

13. Gajic. G and al., 2016. Assessment of the phytoremediation potential and an adaptive response of Festuca rubra L. sown on fly ash deposits: Native grass has a pivotal role in ecorestoration management. Ecological Engineering 93 250-261.

14. Pawlik-Skowronska and al., 2001. Phytochelatin production in freshwater algae Stigeoclonium in response to heavy metals contained in mining water; effects of some environmental factors. - Aquatic Toxicology, vol 52 issue 3-4_Pages 241-249.

15. Zhang. Y, 2013. Ascorbic Acid in Plants, Springer Briefs in Plant Science, 7 DOI:10.1007/978-1-4614-4127-4_2

16. Ontod and al., 2015. Effet des concentrations en manganèse du sol sur la croissance du manioc (Manihot esculenta crantz) au Gabon.

17. Ontod and al., 2013. Effet de la toxicité manganifère sur les paramètres morphométriques de la roselle (Hibiscus sabdariffa L. var. Sabdariffa) au Gabon.

18. Lepengue A. N. and al., 2008. Production, caractérisation et utilisation des composés toxiques de Phoma sabdariffae SACC. dans 
la sélection des cultivars résistants de roselle (Hibiscus sabdariffa var. sabdariffa) au Gabon. Journal Ajol vol $20 \mathrm{n}^{\circ} 1$.

19. Lepengue $\mathbf{A}$. $\mathbf{N}$. and al., 2009. Effet du chlorure de sodium $(\mathrm{NaCl})$ sur la croissance de la roselle au Gabon.

20. Mavoungou and al., 2015. MANGANESE'S EFFECT IN THE SHEET APOPLAST HIBISCUS SABDARIFFA L. VAR SABDARIFFA FOR 10 DAYS. European Scientific Journal August 2015 edition vol.11, No.24 ISSN: 1857 - 7881 (Print) e - ISSN 18577431. 